\title{
BUSINESS EVENTS AND FRIENDSHIP: LEVERAGING THE SOCIABLE LEGACIES
}

\author{
CARMEL FOLEY, DEBORAH EDWARDS, AND KATIE SCHLENKER \\ University of Technology, Sydney, Lindfield, NSW, Australia
}

\begin{abstract}
Business events are celebrated for their contributions to community and industry. They are understood to be shared social contexts in which people meet to advance knowledge, sell products, and network. Less celebrated and, arguably, less understood is that business events provide a context for the development of friendships. In 2011 an online survey was conducted with the delegates of five international business events held in Sydney, Australia in the period 2009-2011. The survey was designed to investigate business legacies of the events (such as investment opportunities, research collaborations) rather than sociable legacies. However, a surprising number of references to friendship were made in the "additional comments" sections of the questionnaire. Reflecting on this finding, this article argues that friendships forged at business events contribute to, respectively: the well-being of delegates, association membership levels, conference attendance, retention of personnel in the profession, successful research and professional collaborations, and creativity and innovation in the sector. Business event planners can maximize opportunities for sociable outcomes among delegates by designing warm and inviting event spaces that facilitate interaction, and by providing social space for the development of relationships, optimal conditions for sociability, and opportunities for play to stimulate creativity and build community.
\end{abstract}

Key words: Business events; Legacies; Friendship; Sociability; Play; Venue design

Introduction

Business events come in many forms, including conferences, conventions, meetings, seminars, summits, exhibitions, training, and recognition and incentive programs (Edwards, Foley \& Schlenker, 2011, p. iii). They are attended for the opportunities they afford delegates for realizing a range of benefits and outcomes in the form of knowledge expansion, networking, relationships and collaboration, educational outcomes, fundraising and future research capacity, raising awareness and profiling, showcasing, and destination reputation (Foley, Schlenker \& Edwards, 2011; Foley, Schlenker, Edwards, \& Lewis-Smith, 2013; Jago \& Deery, 2010). Friendships forged through business events have been a cornerstone of scientific meetings and business activity for many years. As early as 1933, Bassett 
encouraged his colleagues to attend the National Association of Teachers of Speech Convention: "there we shall have an opportunity to meet friends and fellow-workers and enjoy social hours together" (p. 566). It was at such conventions, he argued, that firm bonds of fellowship were established and preserved, as conventions afforded the opportunity for people to meet face to face, know each other, exchange ideas, formulate plans, and determine objectives under the quickening influence of spoken words and personal contacts. Two decades later Cook (1954) sought to persuade his colleagues that the Tax Executive Industry (TEI) conference was "not just a schedule of planned events with which you may be either entertained or bored; nor are its tax sessions designed to serve the purpose of a lecture series. [It is] an opportunity to extend your personal associations, many of which will ripen into lasting friendships” (pp. 3-4).

A literature review has found that, in the business event sector, friendship is a by-product of conference attendance and the level of attention paid to friendship by contemporary business event planners may not be adequate. Most events include a social program-typically comprising a welcome/ reception, conference dinner, and a tour optionbut the sociable aspects of the events are not generally referred to in the objectives or strategic plans for business events.

This article addresses the links between business events and friendship and the benefits that these friendships bring to various stakeholders (delegates, professional associations, industry), and provides a discussion of strategies that can be adopted by business event professionals to maximize opportunities for sociable outcomes among delegates. The following section reviews the literature on friendship and the sociable aspects of business events.

\section{Literature Review}

Friendship is a voluntary relationship, it involves an emotional bond, and the emotional attachment between friends is a reciprocal one (Lynch, 2005). Friendship evolves where there is a "setting and an audience to express unique aspects of [our] personality" and generates trust, reciprocity and a sense of belonging (McMillan, 1996, p. 315). Friendship brings benefits, but relationships engaged in for the sake of those benefits are unlikely to result in friendship. Friendship does not succeed when there are attempts to use others for gain (Lynch, 2005; McDonald, Wearing, \& Ponting, 2008).

Contributions to the literature examining the concept of friendship have been made in almost every century dating back to antiquity (Lynch, 2005). The historical record provides information about ways in which the nature of friendship has changed over millennia along with the changing circumstances of Western life. Urban dislocation, time constraints (Lynch, 2005), and the cult of individualism (McDonald et al., 2008) have altered the way friendship is experienced. According to Lynch (2005) "the heterogeneity of modern life is regarded as making friendship more difficult to sustain for modern individuals than it would have been for the good men of Aristotle's polis" (p. x). Friendship today is less about a complete union between individuals than was the case in earlier eras. In Lynch's (2005) view, modern friends typically share only those aspects of their lives that they have in common, and are aware and tolerant of the need to limit their understanding of each other.

Despite such limitations, friendships continue to be valued and the meanings of friendship emerge in the relationships between people (Lynch, 2005). Finally, it is important to note that the development of friendship among individuals can be fostered or inhibited (Lynch, 2005) by external factors.

Friendship permeates both personal and work spheres. Research in organizational behavior suggests that business friendships are common (Ingram \& Zou, 2008; Turnbull \& Wheeler, 2009; Zcan, 1995) and that they establish mechanisms of trust, empathy, and sympathy as well as common grounds of values, beliefs, and interests.

The friendship that arises from business relationships has been found to result in instrumental benefits for careers and improved organizational performance (Ingram \& Zou, 2008); personal contacts and the sharing and exchanging of information that can lead to decisions regarding strategic activities of the firm (Deans, Gill, \& Apedaile, 1996; Turnbull \& Wheeler, 2009); assessment of market trends (Deans et al., 1996); and tacit collusion and cooperative efforts (Ingram \& Roberts, 2000). Significantly, though, Harris and Wheeler (2005) explain that the origins of these relationships 
are either personal or social and often developed initially without any idea of the eventual outcomes of the relationship.

Bathelt, Malmberg, and Maskell (2004) suggest that innovation, knowledge creation, and learning are all best understood if seen as the result of interactive processes where people possessing different types of knowledge and competencies come together to exchange information. Such exchanges and interactions can occur in different ways, including over the telephone or video conferencing. However if the knowledge is diffuse and tacit then subtle forms of information exchange will only occur where people meet repeatedly in a supporting environment (Bathelt et al., 2004). Business events such as conferences, conventions, and congresses afford such an environment.

Hickson (2006) states that conferences provide opportunities for delegates to become part of a network of lifelong professional and personal friends and that this network can increase exponentially over time. Maskell, Bathelt, and Malmberg (2005) argue that business events are vehicles that allow the interaction between business people and firms to take place, providing a temporal context for intensified knowledge exchange and social interaction. This perspective highlights the relevance (and necessity) of conferences for facilitating the social interaction required for the exchange of visions, opinions, and ideas and for the development of professional and personal friendships. In this respect entrepreneurs interviewed by Bahlmann, Huysman, Elfring, and Groenewegen (2009), who were regular participants of conferences and congresses, stated that the chance to build relationships with other regular participants resulted in improved business performance.

Business events are layered in social outcomes. For example, people who attend trade fairs and interact with one another as competitors, colleagues, or experts during the day can become acquaintances at less formal dinner meetings and gatherings in the evening or outside the event program (Maskell et al., 2005; Uzzi, 1997). Maskell et al. (2005) found that "through consecutive trade fairs and conventions, potential partners get to know one another better so that some level of relational trust can be established. Initial low risk interaction may be gradually intensified in a stepwise manner” (p. 6).
Robert's (2011) work on cross-cultural friendship in the context of missionary associations and Christian conferences in the early to mid-20th century highlights that professional associations (in this case, missionary associations) were comfortable to speak overtly about the role of friendship in their field up until the mid-20th century. Later, terms like "partnership" and "networks" began to replace "friendship" as adjustments were made to account for the increasingly performance-based, isolating, and competitive demands of the latter part of the 20th century (Robert, 2011). Robert notes that the idea of partnership was more corporate and structured and less intimate than that of friendship and questions whether anyone has time these days to make friends as people busily work at cross-cultural networking that "looks good on a résumé” (p. 106).

Small, Harris, Wilson, and Ateljevic (2011) refer to the link between friendship and conferences in their reflection on work-life harmony for women in tourism academia. For Small et al. (2011) conferences provide academics with a break from the usual demands of day-to-day life. A group of women in their study mention, in particular, a break from the demands of family afforded by conference attendance. They also note that the women "experienced harmony when [they] felt at one with those around [them]" and that most of their memories of harmony were of occasions away from offices and universities (pp. 28-29). Their memories of disharmony, on the other hand, were of events in their institutions where they felt isolated. Small et al. (2011) conclude their article with a call for strategic planning to achieve work-life harmony. They make the point that friends work well together and that friendships are important to their well-being. Small et al. (2011) suggest that achieving harmony may require academics to temporarily step outside of the system, to find spaces where they can share "experiences with other like minded people” (p. 34).

In a factor analysis of motivations to attend business events, Fjelstul, Severt, and Breiter (2009) reported that "socialization was . . . a leading influence for attendance" (pp. 39-40). For Baby Boomers socialization was defined as "meeting friends" and "making new friends" (p. 36); in essence, then, building friendships. Generation X respondents were also motivated by meeting friends and making new 
friends and by "spending time with likeminded people” (p. 38). The authors recommend that association planners "increase socialization opportunities for members and attendees" (p. 40). Not only do these sociable aspects make conference attendance and association membership more attractive but research has found that association membership increases retention in the professions (Fjelstul et al., 2009).

Repeat attendance at regularly held business events underpins the establishment of personal and professional friendships among individuals. The nature of friendships linked to business events has not been examined in any great depth except to note that the friendships are not usually begun with outcomes in mind and they emerge in leisurely settings. This finding is supported by the friendship literature, which argues that relationships formed for ulterior motives are not likely to result in friendship. Although friendships are not established for gain, the benefits they generate are evident. Friendships motivate attendance at business events and membership of professional associations. Membership of professional associations increases retention in professions. Friends work well together and this has implications for research and business collaborations.

The next sections present the methodology and findings of the current study where delegates reported on the links between friendship and business events at five international congresses held in Sydney 2009-2011, including the 12th World Congress of the World Federation for Ultrasound in Medicine and Biology 2009 (WFUMB); the 7th International Orthodontics Congress 2010 (IOC); the International Federation of Surveyors Congress 2010 (FIG); the Human Proteome Organisation 9th Annual World Congress 2010 (HUPO); and the Asia Pacific Academy of Ophthalmology Congress 2011 (APAO).

\section{Methodology}

Foley et al. (2011), using Grounded Theory methodology, identified six major themes that reflect the benefits and outcomes that can arise from a business event. These included knowledge expansion; networking, relationships, and collaboration; fundraising and future research capacity; raising awareness and profiling; and showcasing and destination reputation. Using Grounded Theory as the overarching methodology to analyze data from five exploratory case studies assisted the researchers to study the phenomenon in a natural setting and generate theories from practice (Denzin \& Lincoln, 2003; Glaser, 1998). Subsequently these themes were developed into an online survey instrument to test the themes across a larger number of conferences and delegates.

The survey contained three main sections. Section one examined the reasons why exhibitors and sponsors support congresses and the estimated investment they may have received as a result of their support. In Section two, the six major themes were crafted into attribute items and grouped under five broad areas: general benefits and outcomes; individual benefits and outcomes gained; host destination benefits and outcomes; how individuals used benefits and outcomes gained; and how individuals shared benefits and outcomes gained.

Section three asked some general questions about the occurrence of benefits and outcomes, Sydney's reputation as a world-class congress destination, respondents' overall satisfaction with their congress, as well as basic demographic questions. It was in this section that respondents could comment on any other benefits and outcomes they may have realized from attending the conference.

The survey was piloted for clarity, length, and general consistency of results in March 2011, with 20 responses being received (these were subsequently excluded from the final sample). Minor amendments were made to the final version of the survey. The online survey was distributed to 13,200 attendees-comprising delegates, sponsors, exhibitors, and members of the organizing committee- of five international congresses held in Sydney between January 2009 and April 2011 (Table 1). A survey link, embedded into an introductory email, was distributed to attendees of the five congresses progressively from March 30, 2011 by Business Events Sydney, the organization responsible for promoting Sydney as a business events destination, and attracting national and international business events to the city.

As an incentive for response, respondents had the chance to win prizes including a return Qantas airfare from any domestic or international port to Sydney, and an Apple iPad. Surveying closed on 
Table 1

List of Congresses Surveyed

\begin{tabular}{|c|c|c|}
\hline Congress & Date held & $\begin{array}{l}\text { Attendees } \\
\text { (Approx.) }\end{array}$ \\
\hline $\begin{array}{l}\text { 12th World Congress of the World Federation for Ultrasound } \\
\text { in Medicine and Biology (WFUMB) }\end{array}$ & August/September 2009 & $1,400^{\mathrm{a}}$ \\
\hline 7th International Orthodontics Congress (IOC) & February 2010 & $3,600^{\mathrm{b}}$ \\
\hline International Federation of Surveyors Congress (FIG) & April 2010 & $2,200^{\mathrm{b}}$ \\
\hline Human Proteome Organisation 9th Annual World Congress (HUPO) & September 2010 & $994^{\mathrm{a}}$ \\
\hline Asia Pacific Academy of Ophthalmology Congress (APAO) & March 2011 & $5,006^{\mathrm{a}}$ \\
\hline
\end{tabular}

${ }^{a}$ Actual number distributed excluding bouncebacks.

${ }^{\mathrm{b}}$ Attendee estimates taken from individual congress websites.

May 13, 2011. By this deadline 1,441 surveys had been received. Of these 1,090 were deemed valid, in that they had been either completed or nearly fully completed. Some respondents chose not to identify themselves for the purposes of the prize draw; however, this did not invalidate their response.

Quantitative data were analyzed using the Statistical Package for the Social Sciences (SPSS) and are the subject of another paper. Some 305 respondents chose to answer the open-ended questions as to whether there were any other benefits and outcomes they gained from attending the conference. Ethnographic Content Analysis (ECA) was used to analyze these responses. Whereas the topical categories in traditional content analysis are generally predetermined and fixed, central to ECA is its reflexive nature and constant discovery of themes (Altheide, 1987; O’Reilly, 2005). While topical categories may initially guide the study "others are allowed and expected to emerge throughout the study" (Altheide, 1987, p. 68). It is the qualitative findings on friendships forged at business events that emerged from the data, which are the focus of this article.

\section{Findings}

Table 2 presents the profile of respondents as aggregated data from the five congresses. In all, $63 \%$ of respondents were male and $37 \%$ were female. However there were significant differences between the congresses, with females representing $59 \%$ of respondents from WFUMB, and males representing $88 \%$ of FIG respondents. Age distribution was skewed slightly towards older delegates, with
$42 \%$ of all respondents aged 50-plus. However, as with gender, this varied significantly between congresses, with $57 \%$ of FIG respondents aged 50-plus, compared with just $20 \%$ of HUPO respondents. In

Table 2

Respondent Profile $(n=1,090)$

\begin{tabular}{|c|c|}
\hline Variable & $\%$ \\
\hline \multicolumn{2}{|l|}{ Gender } \\
\hline Male & $63 \%$ \\
\hline Female & $37 \%$ \\
\hline \multicolumn{2}{|l|}{ Age } \\
\hline $18-24$ & $1 \%$ \\
\hline $25-29$ & $7 \%$ \\
\hline $30-34$ & $11 \%$ \\
\hline $35-39$ & $13 \%$ \\
\hline $40-44$ & $11 \%$ \\
\hline $45-49$ & $14 \%$ \\
\hline $50-54$ & $18 \%$ \\
\hline $55-59$ & $13 \%$ \\
\hline $60-64$ & $6 \%$ \\
\hline $65+$ & $5 \%$ \\
\hline \multicolumn{2}{|l|}{ Place of residence } \\
\hline Australia/NZ/Pacific & $54 \%$ \\
\hline Africa & $2 \%$ \\
\hline Asia/Middle East & $19 \%$ \\
\hline Central/South America & $8 \%$ \\
\hline Europe & $17 \%$ \\
\hline \multicolumn{2}{|l|}{ Role in congress } \\
\hline Member of organizing committee & $5.3 \%$ \\
\hline Delegate: Academic & $36.6 \%$ \\
\hline Delegate: Practitioner & $52.7 \%$ \\
\hline Sponsor & $0.7 \%$ \\
\hline Exhibitor & $4.7 \%$ \\
\hline \multicolumn{2}{|l|}{ Years worked in main occupation } \\
\hline Less than 2 years & $5 \%$ \\
\hline $2-5$ years & $11 \%$ \\
\hline $5-10$ years & $17 \%$ \\
\hline More than 10 years & $67 \%$ \\
\hline
\end{tabular}


terms of their role at the congress, almost $53 \%$ of respondents were there as practitioner delegates, while academic delegates comprised a further $37 \%$. The exception is HUPO, to which $77 \%$ of respondents were academic delegates. Organizing committee members made up 5\% of the sample, with exhibitors and sponsors comprising the balance. The majority of respondents (54\%) were from Australia, New Zealand, and/or the Pacific. Respondents from Asia/Middle East regions comprised $19 \%$ of respondents, with a further $17 \%$ of respondents from Europe. The large majority of respondents $(67 \%)$ had worked in their main occupation for 10 years or more.

ECA was used to analyze the open-ended questions as to whether there were any other benefits and outcomes respondents gained from attending the conference. Emerging from the data were six main categories of benefits and outcomes, including "broadening networks," "better awareness and appreciation of international practices," "enhanced teaching," “career opportunities,” “appreciation of Australia,” and "friendship.” Each category had an associated set of descriptors arising from the data. With the exception of friendship all other categories were considered to be in line with the questionnaire. That is, they were considered to support the tone of the quantitative questions in the survey and did not add anything new to the findings. The category of "friendship," and its related variants - friends, friendly, relationships - was a theme that had not been addressed elsewhere in the survey nor had it arisen in the Foley et al. (2011) study. Descriptors co-occurring with friends included "new," "old," "reaffirm,” "renew," “visit,” “enhancing,” "warm,” "business," and "social."

Attendees indicated that conferences enable an environment in which to make new friends, reconnect with old friends, visit friends they have in the conference destination, and reaffirm and enhance friendships they have made at previous conferences. As previously found, conferences continue to provide opportunities for delegates to become part of a network of lifelong professional and personal friends that can grow over the years (Hickson, 2006).

"Warm" and "business" referred to the nature of the friendship. For instance, attending a wellrun conference "helps foreigners and provides a warm friendship” suggests feelings of belonging and connectedness. The theme running through the data is that there is an emotional bond between conference attendees. "Business" referred to more instrumental benefits and outcomes such as career opportunities and enhanced practice and business performance. However, these variants are connected as attendees stated that friendships supported new networks, assisted in expanding networks, and increased the interactions an attendee could have at the conference.

"Social" represents activities that offered opportunities related to friendships. The social program, social events, social venues, and social scene were elements that enabled attendees to increase their social interaction. As Maskell et al. (2005) and Uzzi (1997) have argued business events are layered in social outcomes wherein people who interact as competitors, colleagues, or experts during the day can become acquaintances at social meetings and gatherings in the evening or outside the event program.

Business events generate tourism. Larsen, Urry, and Axhausen (2006) argue that a great deal of tourism is about "people" rather than "place" and that "research has neglected issues of sociality and corporeal copresence and thereby overlooked how more and more tourism is concerned with (re)producing social networks” (p. 244). The data collected in this study suggest that congress attendance was also concerned with (re)producing social networks.

The findings of this study, together with previous research into business events and friendship, confirm that friendships forged at business events generate beneficial outcomes at individual, association, and industry levels. The next section draws on a broad range of literature to develop ideas on ways to encourage these sociable legacies from business events. Ideas for enhancing the sociable aspects of business events have been drawn from the literature on sociability and from areas of leisure theory, including Huizinga's (1980) play theory. This body of literature, while extensively used in the leisure field and others, has been underutilized in event studies (Getz, 2007). The discussion that follows presents ideas for leveraging the sociable legacies of business events under the topic areas of time out from daily routines, sociability, play, and designing event spaces. 


\section{Discussion}

\section{Time Out From Daily Routines}

The treadmill of daily existence in Western, neoliberal societies has been identified as a less than ideal environment for forming meaningful relationships with the people around us (McDonald et al., 2008). Busy people in Western societies often find it difficult to let go of their "to do" lists for the sake of spending slow, leisurely hours with companions (Thompson, 1967). However, in order to have opportunities for meaningful social interactions, people need to take time out from their busy schedules and established routines. This is also appropriate in the context of business events, where it is suggested that business event planners maximize the "time-out" opportunities for delegates.

Taking time out to attend a single business event may not be sufficient to establish friendships. Research has identified links between friendship and repeat attendance at annual association conferences and congresses (Hickson 2006; Small et al., 2011). Similarly, Foley and Hayllar (2009), Kyle and Chick (2004), and Marles (2002) have established clear links between repeat visitation to various campgrounds and holiday parks and the development of friendships. Taken out of their regular routine, the regular repeat visitors in each study found the time to develop relationships with their fellow. After a period of time, the resulting friendships became the main motivation for continuing to take the same holiday at the same destination each year.

Foley and Hayllar (2009) argue that for the duration of the caravan park holiday, the participants in their study revert to an older sense of time, let go of the need to engage in "purposive leisure," and adopt a more classical approach to leisure-as a state of being rather than activity (de Grazia, 1962). Their findings indicate that this set of behaviors and attitudes opens up space for developing and maintaining friendships, building aspects of trust and the mutual benefits that come from being part of a transient yet meaningful community, and contributing to and enjoying the symbolic celebration of these intrinsic qualities. Over years of repeat visitation, they argue, the campers have "relearn[ed] some of the arts of living lost in the industrial revolution: how to fill the interstices of their days with enriched, more leisurely, personal and social relations" (Thompson, 1967, p. 95).

Like holidays, business events are shared social contexts that take people away from their established routines (Edwards et al., 2011). Events are, by definition, out of the ordinary experiences (Allen, O’Toole, McDonnell, \& Harris, 2011). Attending a conference allows temporary escape from the dayto-day stresses of ordinary life (Small et al., 2011). It is, in a sense, time out-a break from the usual routine. This "time out" aspect of business event attendance provides the opportunities and space in which friendships might develop, particularly if the delegates are repeat attendees at a regularly held conference.

Summing up, the findings suggest that it would be appropriate for business event planners to maximize the "time out" aspects of conferences wherever possible. Ways of doing this might include loosening tight schedules, increasing the length of breaks, and providing more structured but casual leisure opportunities for delegates; in effect, providing plenty of relaxed social space in which delegates are encouraged to spend time with each other.

\section{Sociability}

Providing relaxed social space for sociable interaction to occur is crucial for supporting the development of friendship but it may not be enough on its own. Georg Simmel, one of sociology's most influential early figures, offers advice for achieving sociability. His work has been used extensively in many fields and offers new insights into the study of events.

According to Simmel (1964), moments of sociability are most often realized in the context of conversation. Sociability exists in those rare moments between people when conversation is gripping, lively, and playful, and has no motive other than the enjoyment that each receives from the interaction. In purely sociable conversation, the topic is merely the indispensable medium through which the lively exchange of speech itself unfolds its attractions. The usual forms of conversation- "quarrel, appeal to norms, pacification by compromise, discovery of common convictions," to name a few-are not used for their usual purposes, but derive their significance 
from "the fascinating play of relations they create among the participants” (Simmel, 1964, p. 52).

While most forms of association between people are driven by ulterior motives, Simmel (1964) considers sociability to be the "play-form" or "pure form" of association, the only form of human to human association to lack "contents" (drives, motives) (p. 43). Sociability has no ulterior end, and no result outside itself, and offers people an "emancipating and saving exhilaration" (Giulianotti, 2005, p. 295).

It is important for "wealth, social position, erudition, fame, exceptional capabilities and merits" not to play any part in sociability (Simmel, 1964, p. 46). Sociability requires objective measures of status to take a back seat so that participants can act as if they were equals. Sociability exemplifies "a classless and democratic ethos or ideal” (Giulianotti, 2005, p. 295).

In an analysis of sociability in the context of Scottish football team supporters, Giulianotti (2005) notes that the Scottish fans pursue an egalitarian ethos and openly declare that regardless of whether you are a "barrister or street sweeper," when you travel with the "Tartan Army you're just the same as everyone else” (p. 296). Foley and Hayllar (2009) had similar findings in their analysis of repeat visitors to caravan parks in Australia where respondents noted that differences in wealth were not a factor in the temporary community of the holiday park. In both cases there is a collective understanding among participants that socioeconomic status is ignored for the sake of the sociable moments while on the holiday or football tour.

While many of the skills of sociability rely on the creativity, playfulness, and good humor of the participants themselves, business event planners may have some influence over the "democratic aspects." Sociability across hierarchies can be awkward. Business event planners often create status hierarchies by providing VIP status to keynote speakers and other "esteemed" participants. This may take the form of special tables at social functions, symbols of status on conference badges, or conspicuous preferential treatment at formal and social gatherings. This focus on social status is not a good basis for the promotion of sociability.

There is scope at most business events to deemphasize status, to make the new post-graduate student feel as welcome as the keynote speaker. This will help to provide optimal conditions for sociability to occur and experiences of sociability are likely to encourage the establishment of friendships among business event participants. This in turn makes attending future events more attractive to delegates and may encourage membership of the relevant associations. In the next section we expand the discussion of play to examine further benefits.

Play

The theme of play is central to many events. Indeed, a significant part of the attraction of many festivals and events is the "invitation" to play. Earlier in the article we established that events, by definition, are "out of the ordinary" experiences. Significantly, "out of the ordinary" is also a characteristic of a play experience (Huizinga, 1980). Most of us are drawn to attend events by the expectation that we are going to have some fun and enjoy ourselves. Events are social spaces in which play is often encouraged. Preeminent play theorist, Huizinga (1980), contends that enjoyment or what he calls the "fun-element" is the thing "that characterises the essence of play" (p. 3) and that "genuine, pure play is one of the main bases of civilization" (p. 5). There is no reason then why opportunities for playful experiences cannot feature as part of the attraction of a business event.

Of particular significance to this study is Huizinga's (1980) contention that a "play-community tends to become permanent even after the game is over" (p. 12). The "feeling of being . . . in an exceptional situation, of sharing something important, of mutually withdrawing from the rest of the world and rejecting the usual norms, retains its magic beyond the duration of the individual game" (p. 12). If you have shared play experiences with someone you often share a bond that continues well after the initial playful event.

Play contains a creative element. Play opens the way for experimentation and allows novel forms of behavior to be tested. Play "can enable an individual to acquire an awareness of the self as a cause of activity which invites transgression of conventional restraints, thus creating time and space out of structure where new social arrangements can be experimented with” (Wearing, 1998, p. 40). The processes 
of play involve creative periods during which the individuals involved investigate or experiment with new or unfamiliar configurations of objects, ideas, and behaviors (Wearing, 1998).

For Huizinga (1980) and Wearing (1998) play and its resolution underpin creativity and human development. If we didn’t play, including playing around with ideas, be it at work or at leisure, there could be no progress in any endeavor (Bateson, 1972).

Play develops friendships and sparks creativity. Creativity is central to innovation. Playful elements have the potential to infiltrate both the scientific and the social forums of business events. The format and style of scientific sessions, paper presentation, and the like might be altered so that delegates are not just a passive audience in the role of spectator, but are actively involved in a more playful style of session. Social events such as the welcome reception and conference dinner can be planned to be less stilted, involving creative and playful aspects.

\section{Designing Event Spaces}

Space is something we cannot touch but it touches us. It surrounds us and envelopes us and any other object in it. Luckily we are able to sculpt and change its appearance and therein lies the secret of good design (Matthews, 2009, p. 59).

Physical spaces play a critical role in enabling or deterring interaction (Bickford \& Wright, 2006). In order to encourage sociable interaction and playful exchange of ideas it is necessary to give some thought to the way conference spaces are designed. The large, cavernous space of a convention or conference venue can appear cold and unwelcoming. However, with attention to design, a cold cavernous void can be changed into a warm and welcoming place.

In a critique of tourist destinations, Wearing and Wearing (1996) use the concepts of "flâneur" and "chora" to illustrate the difference between spaces that are designed to be gazed upon — cold and alienating experiences in which the tourist is merely a spectator-and spaces that are comfortable and inviting, spaces in which people interact. They make the point that tourist destinations should not be designed as spaces in which we gaze at predetermined images, in the tradition of the tourist as “flâneur.” Instead, tourist spaces should be designed for the "chorister," the tourist who interacts in creative ways in "space that gives birth to the living experiences of human beings," space that nurtures, spaces that take meaning from the people who occupy them (Wearing \& Wearing, 1996, p. 233).

Event spaces too should be designed for the choraster. The physical features of event spaces influence the mood of delegates and the way they interact. For example, the physical layouts of rooms with a podium or lecture stand at the front are designed for the flâneur. They imply that the delegate is to gaze passively upon the spectacle of the presenter, and that no interaction is expected or encouraged. In contrast, "soft-seating arranged in a sociofugal petal layout" is the space of a choraster, encouraging spontaneous and informal interaction, allowing people to feel ownership of the space (Pitt \& Bennett, 2008, p. 297). Most people feel more creative in an informal, collaborative setting.

Studies of workplace design have found that group cohesion and the formation of friendships are influenced by the physical setting and that variables include the propinquity, size, and flexibility of spaces and seating arrangements (Bitner, 1992, Pitt \& Bennett, 2008). Bitner (1992) contrasts the highly complex seating arrangements of a resortstyle facility designed to encourage interaction with the typical seating arrangements at most airports, which discourage interaction among waiting passengers. Similar findings are reported in the literature on interactive university learning spaces that recommend rooms being universally designed to be accessible to all, with comfortable, reconfigurable furniture and soft lighting (Bickford \& Wright, 2006).

Small groups generally are more likely to result in livelier conversation than very large groups, and lively conversation is vital for achieving sociability. It is important then to design spaces that are conducive to small group gatherings, spaces in which people interact.

To encourage sociability at business events it may be useful to reduce work-like aspects: for example, to have some social spaces that are Wi-Fi free to encourage delegates to take a break from email and other online forums and make the most of the face-to-face opportunities.

Summing up, if we are to encourage creativity and sociability among delegates it is important 
to design warm and inviting flexible spaces that facilitate interaction and to minimize those design aspects that send the message that the delegate is expected to be a passive spectator.

\section{Conclusion}

Recent research into the contributions made by business events to professions, industry, and community has been investigated within a "businesslike" framework with a focus on outcomes such as investment opportunities; knowledge expansion; networking, relationships, and collaboration; fundraising and future research capacity; raising awareness and profiling; and showcasing and destination reputation (Dwyer, Mellor, Mistilis, \& Mules, 2000; Edwards et al., 2011; Foley et al., 2011; Jago \& Deery, 2010, 2011; Joint Meetings Industry Council, 2008; The Business Events Industry Strategy Group, 2008). In this article we have argued that the sociable legacies of business events also merit attention. The particular focus of this article has been the legacy of friendship.

Business events are shared social contexts that take people away from their established routines. Through this social context the sharing of knowledge and creative ideas occur and common meanings are developed through the interactions (Edwards et al., 2011). The camaraderie and sense of community that develop around the event, the appeal of engaging with other like-minded people, and the friendships that are enhanced and developed contribute to both personal and broader social legacies. Personal legacies include the well-being of delegates and association members. In a broader sense the friendship and sense of community among delegates is likely to contribute to healthy levels of association membership, conference attendance, retention of personnel in the profession, successful research and professional collaborations, and creativity and innovation in the sector.

The development of friendships among individuals can be fostered or inhibited by external factors (Lynch, 2005). This article has explored the concepts of time out, sociability, play, and event spaces in order to generate ideas about ways in which business event planners might leverage the sociable aspects of business events. It is recommended that business event planners: maximize the time-out aspects of events to provide the social space required for the development of relationships; deemphasize the consciousness of status difference among delegates to provide optimal conditions for sociability; provide opportunities for play to stimulate creativity and build community; and design warm and inviting event spaces that facilitate interaction.

The finding on "friendship" as an important benefit or outcome realized from congress attendance was a small but significant finding from a much larger study. It was revealing that the concept of friendship was the only theme identified by respondents that did not link back to previously investigated themes within the questionnaire. This finding suggests that respondents consider friendship to be an important outcome of congress attendance that requires greater recognition. As such, it is suggested that the theme of friendship be added to the current themes of knowledge expansion, networking, relationships and collaboration, fundraising and future research capacity, raising awareness and profiling, and showcasing and destination reputation that reflect the benefits and outcomes that can arise from a business event, as identified by Foley et al. (2011). Further research is suggested, not only to explore the meaning(s) of "friendship" in the context of business events, but to test its existence within the legacy benefits and outcomes across a larger number of business events.

\section{References}

Allen, J., O’Toole, W., McDonnell, I., \& Harris, R. (2011). Festival and special event management (5th ed.). Milton, Australia: Wiley.

Altheide, D. L. (1987). Reflections: Ethnographic content analysis. Qualitative Sociology, 10(1), 65-77.

Bahlmann, M. D., Huysman, M. H., Elfring, T., \& Groenewegen, P. (2009). Global pipelines or global buzz? A micro-level approach towards the knowledge-based view of clusters. VU University Amsterdam, Faculty of Economics, Business Administration and Econometrics, Series Research Memoranda, Number 0002.

Bassett, L. E. (1933). Why conventions? Quarterly Journal of Speech, 19(4), 561-566.

Bateson, G. (1972). A theory of play and fantasy. Steps to an ecology of mind: Collected essays in anthropology psychiatry evolution, and epistemology (pp. 177-193). London: The University of Chicago Press.

Bathelt, H., Malmberg, A., \& Maskell, P. (2004). Clusters and knowledge: Local buzz, global pipelines and the process 
of knowledge creation. Progress in Human Geography, 28(1), 31-56.

Bickford, D., \& Wright, D. (2006). Community: The hidden context for learning. In D. G. Oblinger (Ed.), Learning spaces. Washington, DC: Educause. Retrieved April 4, 2012, from http://net.educause.edu/ir/library/ pdf/PUB7102d.pdf

Bitner, M. J. (1992). Servicescapes: The impact of physical surroundings on customers and employees. Journal of Marketing, 56(1), 57-71.

Cook, H. P. (1954). The annual conference marches on. The Tax Executive, 10, 3-5.

Deans, M., Gill, D. S., \& Apedaile, L. P. (1996). The social networks of rural business owners in East Central Alberta (Project Report 96-02). Edmonton, Canada: University of Alberta, Department of Rural Economy.

deGrazia, S. (1962). Of time, work and leisure. New York: Kraus.

Denzin, N. K., \& Lincoln, Y. S. (Eds.). (2003). Strategies of qualitative inquiry (2nd ed.). Thousand Oaks, CA: Sage.

Dwyer, L., Mellor, R., Mistilis, N., \& Mules, T. (2000). A framework for assessing "tangible" and "intangible" impacts of events and conventions. Event Management, 6(3), 175-189.

Edwards, D., Foley, C., \& Schlenker, K. (2011). Beyond tourism benefits: Measuring the social legacies of business events. Retrieved December 4, 2011, from http://www.busines seventssydney.com.au/fms/About\%20us/Publications $\% 20$ and\%20resources/Documents/Beyond\%20Tour ism\%20Benefits\%20Measuring\%20the $\% 20$ social\%20 legacy\%20of\%20business\%20events.pdf

Fjelstul, J., Severt, K., \& Breiter, D. (2009). An analysis of the motivators and inhibitors affecting association meeting attendance for generation $\mathrm{X}$ and baby boomers. Event Management, 13(1), 31-41.

Foley, C. T., \& Hayllar, B. R. (2009). Freedom to be: Friendship and community at holiday parks. In S. Fleming (Ed.), Leisure and tourism: International perspectives on cultural practice (pp. 33-52). London: Leisure Studies Association.

Foley, C., Schlenker, K., \& Edwards, D. (2011). A scoping study of business events: Beyond tourism benefits. Retrieved December 4, 2011, from http:/www.businesseventssydney. com.au/fms/Latest\%20news/Beyond\%20Tourism\%20 Benefits\%20-\%20Final\%20Report.pdf

Foley, C., Schlenker, K., Edwards, D., \& Lewis-Smith, L. (2013). Determining business event legacies beyond the tourism spend: An Australian case study approach. Event Management, 17(3), 311-322.

Getz, D. (2007). Event studies: Theory, research and policy for planned events. Oxford, UK: Butterworth-Heinemann.

Giulianotti, R. (2005). The sociability of sport: Scotland football supporters as interpreted through the sociology of Georg Simmel. International Review for the Sociology of Sport, 40(3), 289-306.

Glaser, B. G. (1998). Doing grounded theory: Issues and discussion. Mill Valley, CA: Sociology Press.
Harris, S., \& Wheeler, C. (2005). Entrepreneurs’ relationships for internationalization: Functions, origins and strategies. International Business Review, 14(2), 187-207.

Hickson, III, M. (2006). Raising the question \#4 why bother attending conferences? Communication Education, 55(4), 464-468.

Huizinga, J. (1980). Homo ludens: A study of the playelement in culture. London: Routledge.

Ingram, P., \& Roberts, P. W. (2000). Friendships among competitors in the Sydney hotel industry. American Journal of Sociology, 106(2), 387-423.

Ingram, P., \& Zou, X. (2008). Business friendships. Research in Organizational Behavior, 28, 167-184.

Jago, L., \& Deery, M. (2010). Delivering innovation, knowledge and performance: The role of business events. Retrieved December 4, 2011, from http://www.businesseventscouncil. org.au/files/BE_Innov_Report_Mar10.pdf

Jago, L., \& Deery, M. (2011). The holistic value of business events: Interim report-May 2011. Retrieved December 4, 2011, from http://www.mcvb.com.au/por tals/mcvb_com_au/documents/MCVB\%20Beyond\%20 Tourism\%20Interim\%20Report\%2013\%20May\%20 2011.pdf

Joint Meetings Industry Council. (2008). Understanding the value of the meetings industry. Retrieved September 21, 2011, from http://www.themeetingsindustry.org/storage/ perspective-articles/Article_Understanding_the_Value_ 08.10.pdf

Kyle, G., \& Chick, G. (2004). Enduring leisure involvement: The importance of personal relationships. Leisure Studies, 23(3), 243-266.

Larsen, J., Urry, J., \& Axhausen, K. (2006). Networks and tourism: Mobile social life. Annals of Tourism Research, 54(1), 244-262.

Lynch, S. (2005). Philosophy and friendship. Edinburgh: Edinburgh University Press.

Marles, K. (2002). Regular revisitation in caravan parks. In D. Carson, I. Waller, \& N. Scott (Eds.), Drive tourism: Up the wall and around the bend (pp. 41-52). Altona, Australia: Common Ground Publishing.

Maskell, P., Bathelt, H., \& Malmberg, A. (2005). Building global knowledge pipelines: The role of temporary clusters (DRUID Working Paper No. 05-20). Danish Research Unit for Industrial Dynamics.

Matthews, D. (2009). Special event production: The resources. London: Elsevier.

McDonald, M., Wearing, S., \& Ponting, J. (2008). Narcissism and neo-liberalism: Work, leisure and alienation in an era of consumption. Loisir et Societe (Society and Leisure), 30(1), 489-510.

McMillan, D. (1996). Sense of community. Journal of Community Psychology, 24(4), 315-325.

O’Reilly, K. (2005). Ethnographic methods. Milton Park, Abingdon: Routledge.

Pitt, M., \& Bennett, J. (2008). Workforce ownership of space in a space sharing environment. Journal of Facilities Management, 6(4), 290-302. 
Robert, D. (2011). Cross-cultural friendship in the creation of twentieth-century world Christianity. International Bulletin of Missionary Research, 35(2), 100-107.

Simmel, G. (1964). Sociability. In K. Wolff (Ed.), The sociology of Georg Simmel (pp. 40-57). New York: The Free Press.

Small, J., Harris, C., Wilson, E., \& Ateljevic, I. (2011). Voices of women: A memory-work reflection on work-life dis/ harmony in tourism academia. Journal of Hospitality, Leisure, Sport and Tourism Education, 10(1), 23-36.

The Business Events Industry Strategy Group. (2008). National business events strategy for Australia 2020: The business of events-Australia's untapped potential. Retrieved December 4, 2011, from http://www.businesseventscouncil.org.au/ files/BES\%20full\%20doc\%20Nov08.pdf

Thompson, E. P. (1967). Time, work-discipline and industrial capitalism. Past and Present, 38, 56-97.
Turnbull, S., \& Wheeler, C. (2009). Business friendships: A free lunch? Or a source of competitive advantage. Presented at International Conference on Managerial Solutions for the Global and Local Markets: Management of Marketing, Human Resources, Innovation, and Finance During a Crises, Nessebar, Bulgaria, September 9-12.

Uzzi, B. (1997). Social structure and competition in interfirm networks: The paradox of embeddedness. Administrative Science Quarterly, 42(1), 35-67.

Wearing, B. (1998). Leisure and feminist theory. London: Sage.

Wearing, B., \& Wearing, S. (1996). Refocussing the tourist experience: The flâneur and the choraster. Leisure Studies, 15(1), 229-243.

Zcan, G. B. (1995). Small business networks and local ties in Turkey. Entrepreneurship \& Regional Development, 7(3), 265-284. 